\title{
MODEL SOCIAL NETWORK EFFECT ON PRODUCT DESIGN
}

\author{
Madyunus Salayan', Dedy Juliandri Panjaitan² \\ Department of Mathematic Education \\ UMN Al-Washliyah \\ juliandri.dedy@yahoo.com
}

\begin{abstract}
The effect of social networking on business marketing strategies becomes inevitable. Taking a step back, we try to combine and analyze the effect on new product development and then propose a model for designing product deployment through social networks. We construct the issue of preferred stock (Kohli and Krishnamurti 1987), which is a common combinatorial optimization problem used as one of the methods for analyzing aggregated data analysis by marketers to identify products with the largest market share, and showing how to combine social networking securities in the issue of stock options.
\end{abstract}

Key Words: Social Networks, Genetic Algorithm, Marketing.

Abstrak. Efek jaringan sosial pada strategi pemasaran bisnis menjadi tak terelakkan. Mengambil langkah mundur, kita mencari untuk menggabungkan dan menganalisis efek seperti pada pengembangan produk baru dan kemudian mengusulkan sebuah model untuk merancang penyebaran produk melalui jaringan sosial. Kami membangun permasalahan share-of-choice (Kohli dan Krishnamurti 1987), yang merupakan masalah optimasi kombinatorial digunakan umumnya sebagai salah satu metode untuk menganalisis data analisis conjoint oleh pemasar untuk mengidentifikasi produk dengan pangsa pasar terbesar, dan menunjukkan bagaimana untuk menggabungkan efek jaringan sosial dalam permasalahan share-of-choice.

Kata kunci: Social Networks, Genetic Algorithm, Marketing. 


\section{Pendahuluan}

Perkembangan sosial media dan jaringan internet saat ini, menyebabkan kita tidak perlu lagi untuk melakukan perjalanan keluar rumah untuk berinteraksi dengan keluarga, teman maupun kerabat, cukup dengan memiliki alat komunikasi dan jaringan, kita dapat menggunakan untuk terhubung kemana saja. Di masa ini, perkembangan jaringan yang semakin pesat membuat perusahaan - perusahaan menciptakan tekhnologi online shopping, sehingga kita hanya menggunakan alat komunikasi berupa gadget dan internet, pembayaran dengan menggunakan mobile banking, hanya duduk di rumah dan barang yang dipesan akan segera tiba di rumah.

Pengaruh teman sebaya memainkan peranan penting dalam pilihan konsumen atau biasanya dilihat dari manfaat nyata dari konsumen yang lain dalam menggunakan produk yang sama seperti saat mereka menggunakan jaringan sosial mereka. Contoh yang dapat di ambil misalnya adalah alat komunikasi. Perusahaan telekomunikasi biasanya menawarkan diskon besar kepada pelanggan yang berupa keluarga atau anggota kelompok sosial yang menggunakan jaringan telepon yang sama dalam pangilan jaringan yang sama. Ketika anggota dari suatu kelompok sosial harus memilih antara produk jaringan telekomunikasi, adalah wajar untuk memperhitungkan efek jaringan yang positif (atau pengaruh teman sebaya) di samping pada atribut sementara dari produk tersebut dalam membuat pilihan.

Conjoint analysis adalah salah satu alat paling populer dalam desain produk baru untuk mengidentifikasi preferansi pelanggan dan kegunaan untuk tingkat sifat produk yang disebut bagian-berharga yang paling dibutuhkan (Green dan Rao 1971). Telah dipelajari secara luas dalam literatur pemasaran dan telah digunakan untuk merancang berbagai produk dalam praktek. Secara umum, ada dua langkah utama dalam conjoint analisis. Yang pertama adalah pengumpulan data dari konsumen dan yang kedua adalah analisis data ini untuk memperoleh bagian-berharga yang dibutuhkan untuk setiap pelanggan pada setiap tingkat atribut. Setelah analisis ini, bagian- berharga yang didapatkan yaitu data digunakan untuk merancang produk.

\section{Dasar Teori}

Komponen-berharga utilitas yang digunakan sebagai masukan untuk permasalahan share-of-choice untuk mengoptimalkan seleksi tingkat untuk setiap atribut. Dalam masalah ini, orang membeli produk hanya ketika orang mendapatkan kegunaan produk dengan menggunakan produk lebih besar dari atau sama dengan / dia $\backslash$ hambatan ". Hambatan" adalah utilitas nilai di mana yang akan menjadi acuh tak acuh antara melakukan pembelian atau tidak melakukan pembelian. Di penelitian ini, peneliti membuat model efek pengaruh jaringan sosial pada desain produk dengan membuat penyesuaian dengan baik pada permasalahan share-of-choice.Menggunakan notasi yang sama dengan Camm dkk (2006), fokus pada tujuan pertama, share of choice. Di misalkan $M$ dinotasikan banyaknya item pada jajaran produk, masing-masing dengan atribut K. $L_{k}$ dinotasikan sebagai banyaknya tingkat pada atribut $k=1,2, \ldots, K$. Jumlah keseluruhan 
respondens adalah $S$. Parameter $u_{k j}^{s}$ mewakili partworth utilitas tingkatan $j\left(1,2, \ldots, k_{j}=\right.$ $L$ ) pada atribut $k$ untuk responden $s$. dinotasikan kendala utilitas untuk pelanggan $s$ dengan $h_{s}=U_{s}+\varepsilon$ dimana $U_{s}$ merupakan utilitas responden pemesanan dan $\varepsilon$ nilai real positif yang kecil.

Didefinisikan variabel keputusan biner $x_{k j m}, y_{s m}, y_{s}$ sebagai berikut $x_{k j m}=1$ jika level $j$ atribut $k$ dipilih untuk produk $m$ dan 0 sebaliknya. $y_{s m}=1$ jika produk $m$ menawarkan pelanggan sebuah utilitas yang lebih tinggi darinya atau pemesanan utilitas dan 0 seblaiknya. $y_{s}=1$ jika utilitas pemesanan pelanggan terlampaui oleh setidaknya satu produk di dalam jajaran produk dan 0 sebaliknya. Ekspresi (1) - (4) menjadikan formulasi integer programming untuk jajaran produk permasalahan share of choice.

Fungsi tujuan $Z=\operatorname{Max} \sum_{S=1}^{S} y_{s}$

Dengan kendala:

$$
\begin{array}{lc}
\sum_{j=1}^{L} x_{k j m}=1 & k=1,2 \ldots K, m=1,2 \ldots M \\
\sum_{m=1}^{M} y_{s m} \geq y_{s} & s=1,2, \ldots S \\
\sum_{k=1}^{K} \sum_{j=1}^{L} u_{k j}^{s} x_{k j m} \geq h_{s} y_{s m} & s=1,2, \ldots S, m=1,2, \ldots, \mathrm{M} \\
x_{k j m}, y_{s m}, \text { dan } y_{s} \text { adalah biner } &
\end{array}
$$

Dalam model ini, tujuannya adalah untuk memaksimalkan pangsa pasar. Kendala (2) menjamin bahwa orang membeli produk hanya jika Kegunaan dari produk mereka melebihi rintangan mereka. Kendala (3) memastikan bahwa setiap atribut ditugaskan hanya untuk satu tingkat. Perhatikan bahwa tidak ada efek jaringan diperhitungkan dalam model ini.

\section{Permasalahan Share-of-Choice Efek Jaringan Sosial}

Komunikasi antara teman-teman memperkuat kecenderungan terhadap membeli produk yang sama. Mitra dari perilaku dalam model ini adalah penurunan di rintangan seseorang (ini bisa dilihat sebagai mekanisme alternatif peningkatan utilitas yang ketiga di Narayan dkk. 2011).

Banyaknya penurunan hanya terbatas dalam rentang rintangan yang kita definisikan sebagai interval antara rintgang yang tinggi dan rintangan yang rendah. Rintangan dalam masalah desain produk tradisional (yaitu, di mana dianggap tidak ada 
efek jaringan sosial) bisa sesuai dengan tinggi rintangan. Sebuah rintangan yang rendah adalah nilai terkecil dari utilitas rintangan dapat dimiliki (yaitu, ketika semua temanteman membeli produk). Secara khusus peneliti menggunakan pengaruh efek menurun secara linear.

Ketika efek jaringan sosial yang hadir, membawa mereka ke akun dalam model share-ofchoice dapat menyebabkan desain produk dengan pangsa pasar yang lebih tinggi. Contoh berikut ini dibangun untuk menekankan seberapa besar perbedaan bisa menjadi salah pangsa pasar dengan dan tanpa jaringan sosial efek dalam proses desain produk. Pertimbangkan jaringan sosial sederhana dengan 3 orang di mana semua pelanggan terkait satu sama lain, yaitu, grafik sepenuhnya terhubung dengan tiga node. Masalahnya adalah untuk merancang produk dengan atribut tunggal dan memaksimalkan pangsa pasar. Untuk mempermudah, asumsikan bahwa hanya ada dua kemungkinan tingkat untuk atribut ini, level 1 dan level 2.

Data yang sesuai pada utilitas, rintangan tinggi dan nilai-nilai $\Delta$ untuk setiap orang diberikan pada Tabel 1. utilitas 200; 320; 205 untuk menggunakan tingkat 1; 280; 280; 240 untuk menggunakan tingkat 2, dan rintangan tinggi 300; 320; 250 untuk tiga orang, masing-masing. nilai-nilai $\Delta_{s}$ adalah sama untuk setiap orang, 20. Untuk setiap tetangga tambahan membeli produk, rintangan seseorang berkurang 20. Dengan formulasi share of choice yang asli (tanpa efek jaringan sosial) dapat dipecahkan, mudah untuk melihat bahwa solusi optimal adalah memilih tingkat 1; pangsa pasar 1 dan hanya orang 2 pembelian produk. Meskipun efek jaringan sosial belum diperhitungkan dalam tahap desain, jika mereka diizinkan setelah produk diluncurkan, pembelian oleh orang 2 mengurangi rintangan untuk orang 1 dan 3. rintangan mereka saat ini menjadi 280 dan 230 tapi masih lebih tinggi dari utilitas mereka (tidak cukup untuk mendorong mereka untuk membeli produk). Ketika masalah ini dipecahkan dengan mengambil jaringan sosial memperhitungkan secara eksplisit (SOCSNE), solusi optimal adalah memilih level 2 dan pangsa pasar 3 dimana seluruh 3 orang membeli produk. Setiap rintangan diturunkan oleh 40 dalam kasus ini karena 2 tetangga dari setiap orang yang membeli produk (300-40 = 260 vs $280,320-40=280$ vs $280,250-40=210$ vs 240$)$. Dalam contoh ini, mengabaikan efek jaringan sosial dalam desain produk mengarah ke solusi yang tiga kali lebih buruk daripada solusi diperoleh model yang mencakup efek jaringan sosial. Contoh ini dapat digeneralisasi (hanya menambahkan pelanggan ke pasar identik dengan 3 orang) untuk menunjukkan bahwa dalam kasus terburuk, kehilangan pangsa pasar ketika efek jaringan sosial diabaikan dapat berukuran besar sebagai ukuran pasar!

Tabel1. Utilitas, rintangan dan nilai $\Delta_{S}$ untuk sampel 


\begin{tabular}{c|c|c|c|c}
\hline \multirow{2}{*}{ Orang } & \multicolumn{2}{|c|}{ Utilitas } & \multirow{2}{*}{$\begin{array}{c}\text { Rintangan } \\
\text { tinggi }\end{array}$} & \\
\cline { 2 - 3 } & $\begin{array}{c}\text { Level } \\
\text { 1 }\end{array}$ & Level 2 & & \\
\hline 1 & 200 & 280 & 300 & 20 \\
2 & 320 & 280 & 320 & 20 \\
3 & 205 & 240 & 250 & 20 \\
\hline
\end{tabular}

\section{Least Cost Influence Problem (LCIP) Melalui Jaringan Pembeli}

Melihat Tabel 1 di contoh sebelumnya, utilitas untuk level 2 untuk setiap orang yang kurang dari rintangan tinggi yang berarti tidak ada seorangpun yang membeli (mengadopsi) produk di awal. Namun, pangsa pasar sama dengan tiga ketika tingkat ini dipilih untuk atribut. Dengan asumsi, bahwa orang tidak membuat keputusan membeli bersama-sama, untuk mendapatkan pangsa pasar ini kita perlu setidaknya satu orang untuk membeli produk pertama dan mempengaruhi orang lain. Masalah sekunder diperkenalkan dalam penelitian ini berkonsentrasi pada pemesanan ini pembeli selama periode waktu yang terbatas.

Dalam kasus tersebut (ketika masing-masing utilitas lebih kecil dari yang sesuai rintangan untuk setiap orang dalam jaringan), untuk mendapatkan solusi pangsa pasar maksimum dari desain produk dari model SOCSNE, beberapa orang mungkin perlu diberikan insentif untuk melakukan pembelian. Dalam prakteknya, intervensi tersebut tidak tanpa biaya, dan untuk bisnis mereka dapat merenungkan sebagai iklan atau biaya pemasaran, mendistribusikan sampel gratis atau kupon diskon untuk kelompok memilih individu. Berikut insentif dibayar dalam satuan utilitas sama dengan perbedaan antara utilitas seseorang dari produk dan / nya rintangan saat ini.

Setelah seseorang melakukan pembelian, rintangan untuk / tetangga nya diperbarui dan dibandingkan dengan utilitas mereka untuk memeriksa apakah mereka telah mengalami penurunan di bawah mereka. Setiap saat orang baru mengadopsi produk, pembaruan ini dan perbandingan diulang. Jika di beberapa titik tidak ada pembeli baru dan pangsa pasar belum mencapai jumlah yang ditentukan oleh model SOCSNE, orang baru perlu diberikan insentif untuk membeli produk. Meskipun memberikan insentif mengakibatkan pangsa pasar yang lebih besar (sama dengan jumlah yang ditentukan oleh model SOCSNE), itu bisa menjadi mahal. perdagangan di luar adalah subyek masalah kedua dalam makalah ini.

Tujuan dari Least Cost Influence Problem (LCIP) adalah untuk mencapai pangsa pasar model SOCSNE sambil meminimalkan jumlah total insentif yang diberikan. Kami merumuskannya sebagai program integer. Untuk memilih himpunan orang penting untuk memberikan insentif, kami menganalisis urutan pembelian. Kami 
memperkenalkan dimensi waktu buatan, $\mathrm{t}=0 ; 1 ; \mathrm{:::;} \mathrm{T}$ (di mana $\mathrm{T}$ adalah jumlah periode waktu), untuk menangkap pemesanan pembeli. Profil produk, pangsa pasar, dan individu yang akan membeli produk tersebut merupakan masukan untuk model LCIP karena masalah ini dapat diselesaikan setelah solusi untuk model SOCSNE diperoleh.

Jaringan sosial dalam masalah ini, $G^{\prime}$, adalah bagian dari jaringan dalam model SOCSNE dan hanya mencakup node, $V^{\prime}$, yang mengadopsi produk sebagai akibat dari profil produk yang dipilih setelah memecahkan model SOCSNE (yaitu, yang hanya mengcakup node yang $y s=1$ dalam larutan Model SOCSNE) dan ujung-ujungnya menghubungkan mereka, $E^{\prime}$. Ada dua jenis variabel keputusan; zs, $s \in v^{\prime}$, merupakan jumlah insentif yang diberikan kepada orang dan $y_{s t}, s \in v^{\prime} ; t=0 ; 1 ;:: ; T$, adalah variabel biner yang 1 , jika membeli orang dalam periode $t$ dan 0 , sebaliknya. Karena tingkat atribut telah dipilih oleh model pertama (SOCSNE), utilitas satu mendapatkan dengan menggunakan produk hanya dapat direpresentasikan sebagai salah satu parameter, Kami tawarkan, untu setiap orang $s \in v^{\prime}$ Ini adalah penjumlahan dari utilitas dari setiap tingkat yang dipilih di masing-masing atribut. formulasi matematikanya adalah sebagai berikut:

$$
\begin{aligned}
& \text { LCIP : minimize } \sum_{s \in V^{\prime}} z_{s} \\
& \text { Kendala } U_{s} \geq h_{s}^{H} y_{s 0} \quad \forall s \in V^{\prime} \text {, } \\
& U_{s} \geq h_{s}^{H} y_{s t}-z_{s}-\Delta_{s} \sum_{j \in V^{\prime}} a^{\prime}{ }_{j s} y_{j, t-1} \quad \forall s \in V^{\prime}, \forall t \geq 1 \\
& y_{s t} \geq y_{s, t-1} \quad \forall s \in V^{\prime}, \forall t \geq 1 \\
& y_{s t}=1 \quad \forall s \in V^{\prime}, \forall t \geq 1 \\
& y_{s t} \in(0,1) \quad \forall s \in V^{\prime}, \forall t \geq 1
\end{aligned}
$$

\section{Pembahasan}

Sebuah algoritma genetika (GA) (Holland 1975) adalah algoritma pencarian evolusi yang meniru secara alami pemilihan spesies untuk mencapai solusi yang dekat dengan optimal. Kami menggunakan pendekatan GA untuk model SOCSNE karena tiga alasan. Pertama, waktu yang dibutuhkan untuk menyelesaikan model pemrograman integer disajikan secara optimal meningkat dengan pesat dengan ukuran masalah (membuatnya menjadi pilihan komputasi tidak layak). Kedua, karena mempengaruhi efek, bahkan untuk program kecil bilangan bulat keadaan seni pemecahan masalah seperti CPLEX memiliki ketidakstabilan numerik dan salah satunya tidak dapat menemukan solusi yang optimal (khusus CPLEX menemukan solusi optimal yang salah!) untuk masalah ini. Ketiga, pendekatan khusus untuk memecahkan masalah SOC asli tidak dapat diperpanjang dengan mudah untuk masalah SOCSNE. GA menghasilkan solusi berkualitas tinggi dan kuat dalam segi waktu komputasi. 
Untuk permasalahan share-of choice asli, Camm et al. (2006) menggunakan relaksasi Lagrangian dengan metode brach and bound untuk memecahkan masalah dengan benar. Dalam metode ini, sebuah pohon pencarian dikembangkan, di mana setiap tingkat pohon pencarian sesuai dengan atribut produk. Jadi node menyusuri jalan di pohon akan memiliki beberapa tingkat atribut telah ditetapkan. Pohon pencarian dipangkas menggunakanaturan berdasarkan logika. Dengan aturan ini, sebuah node dimengerti jika jalan mulai dari node ini tidak bisa menghasilkan solusi yang layak unggul satu yang sudah dikenal. Ini dievaluasi dengan memeriksa apakah rintangan orang jatuh di kisaran minimum dan maksimum utilitas seseorang mungkin memiliki jika jalan yang diikuti untuk desain produk. Hubungan jaringan antara calon pelanggan dalam penelitian ini mencegah kesimpulan logis seperti karena perbandingan utilitas dari produk dan rintangan termasuk efek jaringan sosial yang tergantung pada status pembelian seseorang tetangga. Perhitungan nilai obyektif di setiap node masih akan membutuhkan solusi dari model integer programming yang diusulkan dalam penelitian ini yang secara signifikan akan memperlambat metodologi dan benar-benar membuatnya pada perangkat keras. Untuk kasus desain produk-line, metode yang efisien disajikan dan dibandingkan dengan Belloni et al. (2008).

Berikut ini akan disajikan garis besar dan rincian algoritma genetika. Diasumsikan pembaca sudah memiliki beberapa keakraban dengan algoritma genetika.

Garis besar Algoritma Genetika untuk permasalahan SOCSNE

Input : Parameter: ukuran populasi, tingkat mutasi, jumlah generasi.

Data: jumlah atribut, jumlah tingkat untuk setiap atribut, jaringan sosial masyarakat, tinggi dan rintangan rendah untuk setiap orang, utilitas untuk setiap orang.

Output: Direkomendasikan desain produk, pangsa pasar dari desain produk yang dipilih. Tahap 1 [GENERATE] Mengahasilkan populasi awal dari profil produk q.

Set $t=0$.

Tahap 2 [EVALUATION] Hitung fitness dari setiap profil produk dan andaikan yang TERBAIK = profil dengan fitness terbesar.

Tahap 3 [CROSSOVER] Performa single - operasi point crossover untuk menghasilkan $q$ off springs.

Tahap 4 [MUTATION] Perform mutasi.

Tahap 5 Hitung fitness dari setiap profil produk. Jika nilai fitness terbesar > BEST, update BEST.

Tahap 6 [REDUCTION] Mengurasi jumlah populasi sebanyak setengahnya dengan memilih nilai finess terbesar. $t=t+1$.

Tahap 7 Jika $t<$ Jumlah generasi, maka menuju tahap 3.

Else, STOP.

GENERATE : Setiap individu dalam populasi adalah profil produk dan diwakili oleh serangkaian biner. $\sum_{K=1}^{K} L_{k}$ dimana $L_{k}$ jumlah tingkat untuk atribut $k$. Populasi awal 
dihasilkan acak dengan menetapkan satu tingkat untuk setiap atribut. Misalnya, jika produk memiliki 2 atribut, warna dan ukuran dengan 2 dan 3 tingkat sebagai (hitam, putih) dan (kecil, menengah, besar) masing-masing, maka produk dengan warna putih dan ukuran kecil akan direpresentasikan sebagai (01 100).

EVALUASI : Setelah populasi dibangkitkan, setiap profil produk dalam populasi adalah dievaluasi untuk kebugaran. Evaluasi dari profil produk sesuai dengan menghitung pangsa pasar jika profil produk diluncurkan di pasar. Nilai yang tepat dari pangsa pasar mudah ditentukan dengan nilai-nilai $x_{k l}$ yang diberikan untuk profil yang (misalnya, dengan memecahkan program bilangan bulat SOCSNE Model dengan nilai-nilai $x_{k l}$ tetap). Metode yang digunakan untuk menghitung kebugaran harus dipilih dengan hati-hati. Di pendekatan sebelumnya, kami menggunakan fungsi kebugaran perkiraan (di mana jumlah orang mengadopsi produk dihitung hanya dengan membandingkan rintangan dengan utilitas sementara rintangan diperbarui setelah setiap pembelian) yang hasil dari algoritma genetika secara signifikan lebih buruk. Menggunakan evaluasi yang tepat melalui program bilangan bulat (misalnya dengan pemecahan masalah CPLEX) sesuai untuk pendekatan hybrid disebut MATHEURISTICS (Maniezzo et al. 2009) mengkawinkan pemograman matematika dengan pendekatan metaheuristik.

Crossover : Pada langkah ini, dua profil produk anak diproduksi oleh dua produk profil orang tua. Orangtua dipilih dari populasi tertentu sehubungan dengan fitness mereka, menggunakan Roulette pada Mekanisme roda (Michalewicz 1996). Hal ini memungkinkan individu dengan fitness lebih tinggi, lebih mungkin untuk dipilih sebagai orang tua. Keturunannya membawa sifat kedua orang tua. Kami menggunakan satu-titik crossover untuk menentukan bagaimana warisan tersebut dilakukan untuk generasi baru dari individu. Titik dipilih secara acak dari titik di mana representasi biner dari masing-masing atribut berakhir. Salah satu keturunannya mendapat entri dari orang tua pertama dan entri setelah itu dari orang tua kedua. Keturunan lainnya mendapat sifat dari atribut setelah titik bahwa dari orang tua pertama dan sifat atribut sebelum titik itu dari orang tua kedua. Langkah ini dilakukan sampai jumlah keturunan dibuat sama dengan ukuran populasi, sehingga ukuran penduduk dua kali lipat pada akhir tahap ini. MUTASI : Mutasi di profil produk yang digunakan untuk menggabungkan arah yang berbeda pada proses pencarian. Hal ini sesuai dengan membuat perubahan dalam profil produk dan menciptakan individu yang sifatnya tidak semua diwariskan dari orang tua. Setiap individu dalam populasi mengalamilangkah ini, namun mutasi terjadi dengan tingkat mutasi yang telah ditetapkan atau probabilitasnya. Di dalam algoritma, mutasi dilakukan dengan mengubah tingkat salah satu atribut ke tingkat lain. Jika sebuah profil tunduk pada mutasi, setiap atribut memiliki peluang yang sama untuk berubah. Demikian pula, semua tingkat lain sama-sama mungkin akan dipilih untuk menjadi tingkat yang baru. Ketika seorang individu bermutasi, hanya versi bermutasi tetap dalam populasi. Jadi, pada akhir fase ini, ukuran populasi tetap sama. 
REDUKSI : Ukuran populasi dibelah dua dengan menghilangkan individu dengan pangsa pasar paling sedikit. Sisi lain dari profil dengan pangsa pasar yang lebih tinggi dibawa ke generasi berikutnya.

KONDISI BERHENTI : Proses ini diulang hingga salah satu tidak ada peningkatan yang signifikan selama beberapa generasi atau sejumlah yang telah ditetapkan iterasi tercapai.

\section{Kesimpulan}

Artikel mengusulkan model baru untuk mencakup efek pengaruh teman sebaya dalam desain produk dalam kerangka permasalahan share - of - choice (SOC). Meskipun permasalahan share - of - choice telah dipelajari dalam literatur pemasaran, untuk pengetahuan kita efek pengaruh teman sebaya tidak pernah secara eksplisit dipertimbangkan sebelumnya dalam proses desain produk. Dalam model ini, kami mencoba untuk mengembangkan produk baru mengambil efek jaringan sosial, sebelum intervensi selama fase pemasaran dengan promosi yang ditargetkan. Dengan mempertimbangkan efek pengaruh teman sebaya, dengan model yang baru, kami mampu merancang produk dengan pangsa pasar yang jauh lebih besar dari yang diperoleh oleh model SOC asli.

\section{Daftar pustaka}

[1] Balakrishnan, P. V., dan Jacob, V. S. (1996). Genetic algorithms for product design, Management Science, Vol. 42, No. 8, hal. 1105-1117, August Issue.

[2] Bell, D.R.,dan S. Song. 2007. Neighborhood effects and trial on the internet: Evidence from online groceryretailing. Quantitative Marketing and Economic. Vol 5. hal 61-400.

[3] Camm, J. D., Cochran, J. J., Curry, D. J., dan Kannan, S., Conjoint Optimization: An exact branch-and-bound algorithm for the Share of Choices problem, Working Paper, College of Business, University of Cincinnati, February 2006.

[4] Chen, K. D., dan Hausman, W. H. (2000). Mathematical properties of the optimal product line selection problem using choice-based conjoint analysis, Management Science, Vol. 46, No. 2, hal. 327-332, February Issue.

[5] Green, P. E., dan Krieger, A. M. (1993). Conjoint analysis with product-positioning applications, Chapter 10, Handbooks in OR \& MS, Vol. 5, hal. 467-515.

[6] Green, P. E., Srinivasan, V. (1990). Conjoint analysis in marketing: New developments with implications for research and practice, Journal of Marketing, pp. 3-19, October Issue.

[7] Kohli, R., dan Krishnamurti, R. (1987). A heuristic approach to product design, Management Science, Vol. 33, No. 12, hal. 1523-1533, December Issue.

[8] Kohli, R., Krishnamurti, R. (1989). Optimal product design using conjoint analysis: Computational complexity and algorithms, European Journal of Operational Research, vol. 40, hal. 186-195. 
[9] Krieger, A. M., Green, P. E., Wind, Y. J. (2004). Adventures in Conjoint Analysis: A Practitioner's Guide to Trade-Off Modeling and Applications, (download dari Prof. Green's Official web-page).

[10] Leenders, R.T., J. van Engelen, J. Kratzer. (2003). Virtuality, communication, and new product team creativity: A social network perspective. Journal of Engineering and Technology Management. hal 69-92.

[11] Iyengar, R., S. Han, S. Gupta. (2009). Do friends influence purchases in a social network? HarvardBusinessSchool Marketing Unit Working Paper No. 09. hal.123

[12] Manchanda, P., Y. Xie, N. dan Youn. (2008). The role of targeted communication andcontagion in productadoption. Marketing Science vol.27 no.6. hal. 961-976.

[13] McCullough, D. (2002). A user's guide to conjoint analysis, Marketing Research, Vol. 14 , No. 2.

[14] Orme, B. (2003). Which conjoint method should I use? Sawtooth Software Research Paper Series.

[15] Orme, B. (2005). Pedagogical material on Conjoint Analysis Methodology, Sawtooth Software Inc., (file di download dari www.sawtoothsoftware.com).

[16] Shi, L., Olafsson, S. (2000). Nested partitions method for global optimization, Operations Research, Vol. 48, No. 3, hal. 390-407, May-June Issue.

[17] Sosa, M.E., S.D. Eppinger, C.M. Rowles. 2004. The misalignment of product architecture and organizational structure in complex product development. Management Science vol.50. no.12 hal 1674-1689.

[18] Srinivasan, R., G.L. Lilien, A. Rangaswamy. (2004). First in, first out? The effects of network externalities onpioneer survival. Journal of Marketingvol.68, no.1. hal 4158.

[19] Tull, D. S., Hawkins, D.I. (2003). Marketing Research - Measurement \& Method,

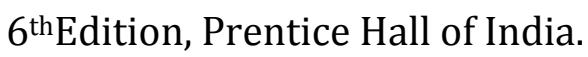

[20] Wind, J., (1982). Product Policy: Concepts, Methods and Strategy, Chapter 10, hal. 290- 293.

[21] Yoo, D., Ohta, H. (1995). Optimal pricing and product-planning for new multiattributeproducts based on conjoint analysis, International Journal of Production Economics, 38, hal. 245-253. 